David Bardey

Danilo Aristizábal

Bibiana Sáenz

Santiago Gómez 
Serie Documentos Cede, 2020-42 ISSN 1657-7191 Edición electrónica. Octubre de 2020

(C) 2020, Universidad de los Andes, Facultad de Economía, CEDE. Calle 19A No. 1 - 37 Este, Bloque W. Bogotá, D. C., Colombia Teléfonos: 3394949- 3394999, extensiones 2400, 2049, 2467

infocede@uniandes.edu.co

http://economia.uniandes.edu.co

Impreso en Colombia - Printed in Colombia

La serie de Documentos de Trabajo CEDE se circula con propósitos de discusión y divulgación. Los artículos no han sido evaluados por pares ni sujetos a ningún tipo de evaluación formal por parte del equipo de trabajo del CEDE. El contenido de la presente publicación se encuentra protegido por las normas internacionales y nacionales vigentes sobre propiedad intelectual, por tanto su utilización, reproducción, comunicación pública, transformación, distribución, alquiler, préstamo público e importación, total o parcial, en todo o en parte, en formato impreso, digital o en cualquier formato conocido o por conocer, se encuentran prohibidos, y sólo serán lícitos en la medida en que se cuente con la autorización previa y expresa por escrito del autor o titular. Las limitaciones y excepciones al Derecho de Autor, sólo serán aplicables en la medida en que se den dentro de los denominados Usos Honrados (Fair use), estén previa y expresamente establecidas, no causen un grave e injustificado perjuicio a los intereses legítimos del autor o titular, y no atenten contra la normal explotación de la obra.

Universidad de los Andes | Vigilada Mineducación Reconocimiento como Universidad: Decreto 1297 del 30 de mayo de 1964. Reconocimiento personería jurídica: Resolución 28 del 23 de febrero de 1949 Minjusticia. 


\title{
Concentration of the Mobile Telecommunications Markets and Countries' Competitiveness*
}

\author{
David Bardey ${ }^{\dagger} \quad$ Danilo Aristizábal ${ }^{\ddagger} \quad$ Bibiana Sáenz ${ }^{\S}$ \\ Santiago Gómez $\mathbb{I}$
}

\begin{abstract}
Developing a database that includes 59 countries, our study sheds light on the role of mobile telecommunications markets' concentration on countries' competitiveness. Performing several estimations and using an instrumental variable that aims to explain the degree of concentration in mobile phone markets, we find that the higher is the concentration in this industry, the lower is the use of the information technology and communication (ICT). On the other hand, we also find that the use of ITC is positively correlated to countries' competitiveness. Thus, our results reveal positive spillover effects of the mobile phone industry on countries' competitiveness and suggest that all policies that aim to reduce concentration and market power in the mobile phone industry is welcomed.
\end{abstract}

JEL: L11, O33.

Keywords: Market structure, Concentration, Competitiveness, Telecommunications industry.

${ }^{*}$ This work has been developed after a consulting project done by CEDE for Telefonica (Colombia). The authors all participated to this project, David Bardey, Danilo Aristizábal and Bibiana Sáenz for CEDE, Santiago Gómez for Telefonica. The authors thank Telefonica (Colombia) for its financial support and access to data bases.

${ }^{\dagger}$ Full Professor at Universidad de los Andes and Visiting fellow at Toulouse School of Economics. Corresponding author: d.bardey@uniandes.edu.co

${ }^{\ddagger}$ Department of Economics, PhD Student at Universidad de los Andes. Corresponding author: de.aristizabal411@uniandes.edu.co

${ }^{\S}$ Consultant. Corresponding author saenz.bibiana@gmail.com

IUniversidad de los Andes - Telefonica. Corresponding author: js.gomez2475@telefonica.com 


\title{
La concentración en el mercado de telecomunicaciones móviles y la competitividad de los países*
}

\author{
David Bardey ${ }^{\dagger} \quad$ Danilo Aristizábal ${ }^{\ddagger} \quad$ Bibiana Sáenz ${ }^{\S}$ \\ Santiago Gómez $\mathbb{I}$
}

\begin{abstract}
Este documento presenta los resultados de un análisis econométrico elaborado para una muestra de 59 países sobre la relación entre la concentración del mercado de telecomunicaciones móviles y la competitividad de un país. Incorporando en el modelo una variable instrumental asociada al grado de concentración en el mercado móvil, pudimos verificar que: i) a mayor concentración del mercado, menor uso de las Tecnologías de la Información y las Comunicaciones (TIC), y que ii) el uso de las TIC está correlacionado positivamente con la competitividad de los países. En consecuencia, el modelo propuesto nos permite corroborar el impacto transversal del sector TIC sobre el desempeño económico de los países, lo que a su turno señala la necesidad de implementar políticas públicas orientadas a reducir la concentración y el poder de mercado en el sector de telecomunicaciones móviles.
\end{abstract}

JEL: L11, O33.

Palabras clave: competitividad, competencia, poder de mercado, telecomunicaciones móviles, concentración.

${ }^{*}$ Este trabajo ha sido realizado después del proyecto de consultoría hecho por el CEDE para Telefónica (Colombia). Todos los autores participaron de este proyecto David Bardey, Danilo Aristizábal and Bibiana Sáenz representando el CEDE, Santiago Gómez a Telefonica. Los autores agradecen a Telefónica (Colombia) por su apoyo financiero y el acceso a sus bases de datos.

${ }^{\dagger}$ Professor Titular de la Universidad de los Andes and miembro de profesores visitantes de Toulouse School of Economics. Correo electrónico: d.bardey@uniandes.edu.co

${ }^{\ddagger}$ Facultad de Economía, Estudiante $\mathrm{PhD}$ de la Universidad de los Andes. Correo electrónico: de.aristizabal411@uniandes.edu.co

${ }^{\S}$ Consultora. Correo electrónico: saenz.bibiana@gmail.com

$\mathbb{I}$ Universidad de los Andes - Telefónica. Correo electrónico: jose.gomez@telefonica.com 


\section{Introduction}

Several researches have revealed the role of Information Technology and Communications (ICT hereafter) on the productivity of firms and countries, showing the usefulness of a public policy that focuses on the promotion of the economy digitisation. Digitisation requires access to infrastructure while this access depends fundamentally on the investment in the deployment of networks and facilities supplied by the telecommunication sector. These investments realised by telecommunication firms depend on the competition intensity in this sector in a convoluted way. On the one hand, when the competition intensity is too weak, firms do not face sufficiently pressure to invest. On the other hand, too much competition erodes profits that are necessary to invest in this industry characterised by high sunk costs. Thus, our objective is to shed light on the role of the competition intensity in the mobile telecommunications on the countries' competitiveness through the channel of ICT use.

In this study we merge two databases that collect information from 59 countries to measure whether the concentration of the mobile market has an impact on countries' competitiveness. More precisely, we use the database of the Global Competitiveness Index of the World Economic Forum to extract information that measures the degree of countries' competitiveness. On the other hand, the database of the mobile market provided by the Global System for Mobile Communications shares information related to the degree of concentration in mobile phone markets that works as a good proxy of the competition degree.

We perform a first regression to highlight the statistical relationship between the level of concentration in mobile phone markets and the degree of countries' competitiveness. Using a panel data, allowing for fixed effects and introducing usual control variables for this kind of cross-countries study, our results indicate that a higher concentration in the mobile phone industry is related to a lower level of competitiveness. Nevertheless, this first regression does not allow us to infer the causality relationship between these two variables and we cannot rule out that countries' competitiveness also explain the degree of concentration in mobile phone markets.

Thus, we propose a decomposition of this statistical relationship to establish more clearly the causal relationship between these two variables. More precisely, our decomposition contains two stages. In the first stage, we perform a linear regression where the dependent variable is the ICT use that aims to capture the degree of digitisation, while the independent variables considered measure the degree of competition of mobile phone mar- 
kets and contain a battery of control variables. Additionally, we use an instrumental variable that captures the degree of strictness of antitrust policy in different countries. Our claim is that antitrust policy strictness may directly affect the degree of competition in mobile phone markets without directly affecting the countries' degree of digitisation. We find that a higher degree of concentration in the mobile phone markets causes, on average, a reduction of 0.45 points (it is a scale of 1 to 7 ) at the level of digitisation of the countries' economies.

In a second stage, we analyse for these same countries the statistical relationship between some digitisation indicators and the countries' competitiveness indicators. Yet, we perform an OLS regression with fixed effects. Our results show that, on average, higher levels of digitisation correlate positively with higher competitiveness. Thus, our decomposition allows us to point out a negative and significant causal relationship between the concentration of mobile phone markets and countries' competitiveness.

In section 2 we provide a brief review of literature. In section 3 we present the sources of information used in this study and some descriptive statistics of the variables we constructed. In section 4 we explain the empirical strategy adopted. Our results are given in section 5 and we conclude in section 6 .

\section{Literature Review}

There are numerous empirical studies that have addressed the relationship between the telecommunication sector's features and the competitiveness of countries' economies. We highlight the most relevant articles for our analysis, both for the direct estimation of the concentration ratio in mobile phone markets with the competitiveness indicators of the countries, as well as those related to our two stages procedure.

Regarding the direct impact of the mobile phone industry and countries' competitive-

ness, Gruber and Koutroumpis (2011) estimate the impact of mobile telecommunications on economic growth, finding that the penetration of this technology has positive effects on economic growth and productivity, and that a causal relationship between these variables can be established. Moreover, their results reveal that the impact of mobile telecommunications on economic growth is due to the direct effect of infrastructure investment, but also to all spillover effects that result from the use of these networks and that facilitate interaction between individuals by shortening distances, facilitating remote work, avoiding unnecessary travel, all for the benefit of quality of life and productivity. Similarly, Grims et al. (2012) 
results confirm that the adoption of broadband increased the productivity of firms in New Zealand by 7 to 10\%. Both results point into the same direction: digitisation improves competitiveness. Our direct estimation gives similar results albeit we do not have established a direct causal relationship between mobile phone competition and countries' competitiveness.

Several articles are related to our first-stage estimation. For the two forces already mentioned in the introduction, the relationship between telecommunications market structure and digitisation as part of understanding determinants of Internet diffusion and liberalisation policy impacts on ICT adoption remains unclear. First, Friesenbichler (2007) as well as Frontier Economics report published in 2017 suggested that there is an inverted-U relationship between market concentration and investment for Latin American mobile markets. Second, Hargittai (1999) empirical study points out that economic wealth and telecommunications policy are the most relevant predictors of countries' Internet connectivity, while monopoly in telecommunication sector seems to have a negative impact on connectivity. Conversely, Kiiski and Pohjola (2002) show that market liberalization itself does not guarantee greater Internet diffusion, unless it is done with a reduction in market prices on those services. Using data on Internet hosts per capita for a sample of the OECD countries during 1995-2000, they find that competition in telecommunications markets does not have any direct effect on Internet penetration. Finally, Billon et al. (2009) provides a canonical correlation analysis for 142 countries in 2004 to explain the differences in ICT diffusion for different groups of countries. The explanatory variable set includes dummy variables for the level of competition for digital cellular mobile services. From their results, they recommend that deregulation, liberalisation and competition measures in telecommunication infrastructures and services might boost Internet use in less-developed economies.

Regarding the literature dealing with our second stage, in a report prepared for the OECD, Gal et al. (2019) found a robust statistical relationship between digitisation and productivity of firms using data from countries belonging to the European Union. Their results indicate that digitisation is more beneficial in manufacturing firms than in service firms, confirming previous results from Akerman, Gaarder and Mogstad (2013) and Dhyne et al. (2018). Gal et al. (2019) also concluded that the impact of digitisation is higher in industries with repetitive processes; result aligned with Chevalier and Luciani (2018). The results we obtained in the second stage of our decomposition come to corroborate these empirical findings, even though we do not enter into the details of firms' sectors. 


\section{Data}

For the construction of our empirical estimations we use data from two sources of information for the period 2007-2017: the database of the Global Competitiveness Index of the World Economic Forum and the database of the mobile market from the Global System for Mobile Communications.

\subsection{Global Competitive Index (GCI)}

The World Economic Forum (WEF) defines competitiveness as "the set of institutions, policies and factors that determine the level of productivity of a country." In this sense, the GCI calculated annually by the WEF is the result of weighted performances of each country in 12 aspects that, according to the WEF, reflect the quality of institutions, policies and all factors that promote productivity and competitiveness. Each of these pillars is composed of sub-pillars and indicators evaluated qualitatively, through surveys aimed at businessmen in each country, or quantitatively by going to statistics provided by official sources recognised in each subject. In Appendix 1 we summarise the decomposition of the pillars realised by the WEF. In this study, instead of using the GCI directly we rather use its decomposition into pillars, and in specific cases that will be pointed out later, some indicators that feed a pillar are also used directly.

More precisely, to measure competitiveness, we use pillars 8 (Financial market development), 10 (Market size), 11 (Business sophistication) and 12 (Innovation), defined by the WEF as follows:

- Pillar 8 - Financial market development: qualifies to what extent the financial market of a country is reliable, transparent, adequately regulated to protect investors and other economic actors, efficient to meet the needs of companies, affordable (credits and services financial), can be financed through the local stock market and if it has risk capital.

- Pillar 10 - Market Size: believes that increasing the market available for a country's firms allows them to take advantage of scale economies.

- Pillar 11 - Business sophistication: assesses the quality of a country's business networks, and the operational and strategic quality of individual firms. 
- Pillar 12 - Innovation: assesses investment in Research and Development by the private sector, the presence of high quality scientific research institutions, the level of university-industry collaboration in research and technological development and property protection intellectual.

The Pillar 9 - Technological readiness and its decomposition is used as a digitisation measure. This pillar captures the agility with which a country adopts existing technologies, especially ICT, to promote the productivity of its industries. Through this pillar the WEF recognises the importance of ICT in competitiveness. More precisely, the pillar considers the level of technological adoption and the penetration of voice and internet services through fixed and mobile networks in the population (Appendix).

Pillars 1 (Institutions), 2 (Infrastructure), 3 (Macroeconomic environment), 4 (Health and primary education), 5 (Higher education and training), and 7 (Labor market efficiency) are used as control variables. For the proper use of pillar 2 (Infrastructure), we build a new variable from it eliminating the telecommunications dimension incorporated by the WEF to avoid obvious problems of endogeneity. Finally, the decomposition of pillar 6 - Efficiency of the goods market, and specifically the indicator that evaluates the effectiveness of the antitrust policy, is used as an instrumental variable in the two-stage model.

\subsection{Global System for Mobile Communications (GSMA)}

This organisation builds a quarterly database that contains information on the mobile market of 60 countries. For the present study of this database, the Hirschman-Herfindhal Index of the telecommunications market reported for the last quarter of each year between 2007 and 2017 was taken to measure the concentration of the mobile market.

\subsection{Exploratory analysis}

As Table 1 shows, our concentration variable is negatively correlated with digitisation and competitiveness variables, except with the development of financial market (the correlation is close to zero). Likewise, the two digitisation variables are positively correlated with the

four competitiveness indicators. This information gives us indications in favor of a possible negative effect of the level of concentration of the mobile phone market on digitization, thus affecting the competitiveness of countries. 
Table 1: Correlation matrix

\begin{tabular}{llrrrrrrr} 
& \multicolumn{1}{c}{ HHI } & ICT Use & P9 & P8 & P10 & P11 & P12 \\
\hline Concentration & HHI & 1 & & & & & & \\
\hline \multirow{2}{*}{ Digitisation } & ICT Use & $-0,05$ & 1 & & & & & \\
& P9 & $-0,15$ & 0,81 & 1 & & & & \\
\hline \multirow{5}{*}{ Competitiveness } & P8 & 0,02 & 0,65 & 0,53 & 1 & & & \\
& P10 & $-0,33$ & 0,12 & 0,14 & 0,00 & 1 & & \\
& P11 & $-0,09$ & 0,80 & 0,79 & 0,69 & 0,30 & 1 & \\
& P12 & $-0,15$ & 0,85 & 0,82 & 0,65 & 0,24 & 0,92 & 1 \\
\hline
\end{tabular}

In Figure 1 we show these relationships disaggregated by income classification (i.e., developed and developing countries). We observe a strong negative relationship between concentration in the mobile phone market and market size of the economy for both developed and developing countries. Additionally, we observe that for less developed countries the relationship between concentration and competitiveness is more pronounced than for developed countries. Similarly, Figure 2 shows the scatter plot between HHI and our digitisation variables. There is a negative relationship between market concentration and digitisation, and it is stronger for developing countries, while for developed countries this relationship remains unclear. 


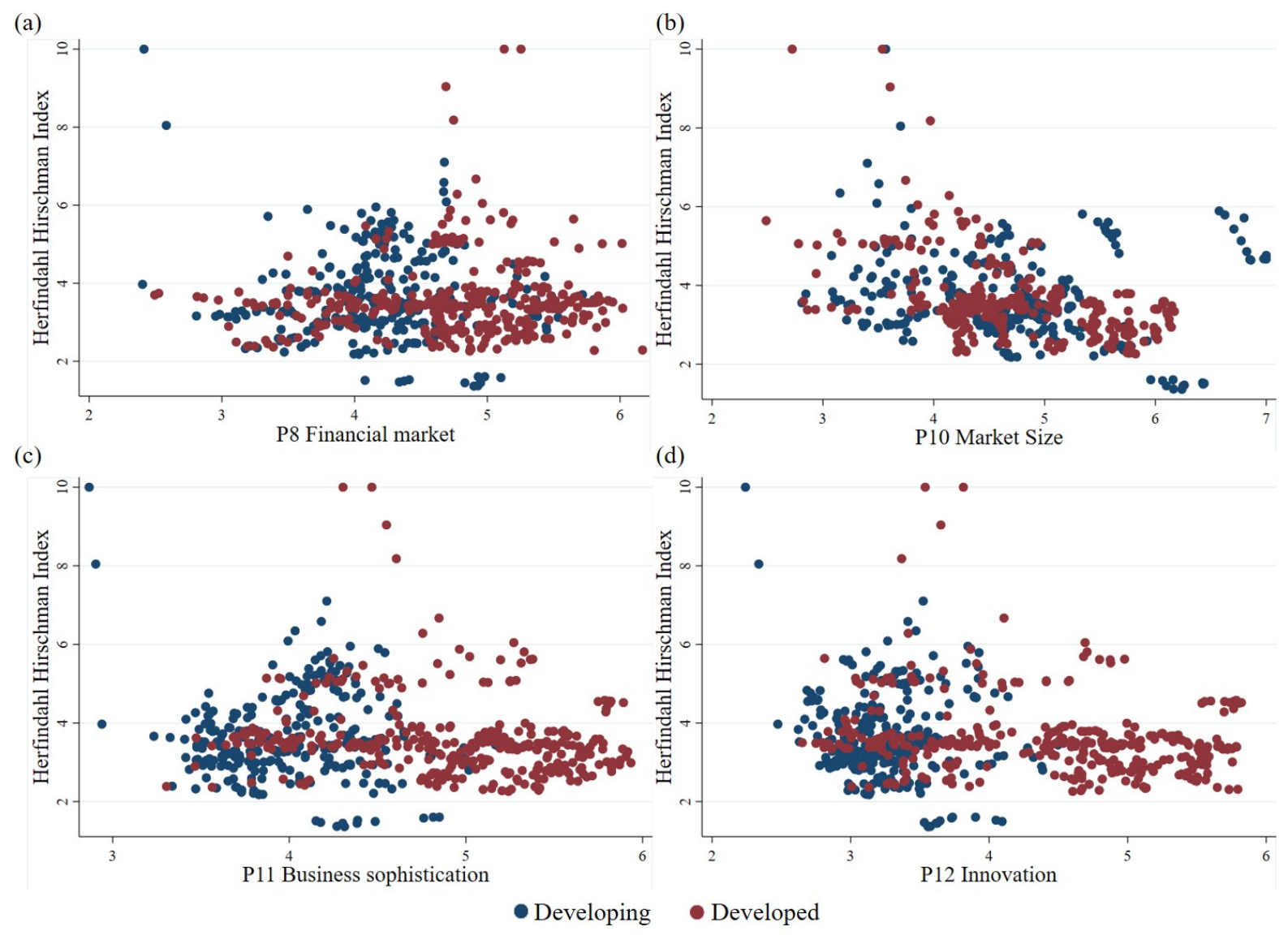

Figure 1: HHI vs Competitiveness

Source: Author's calculations.
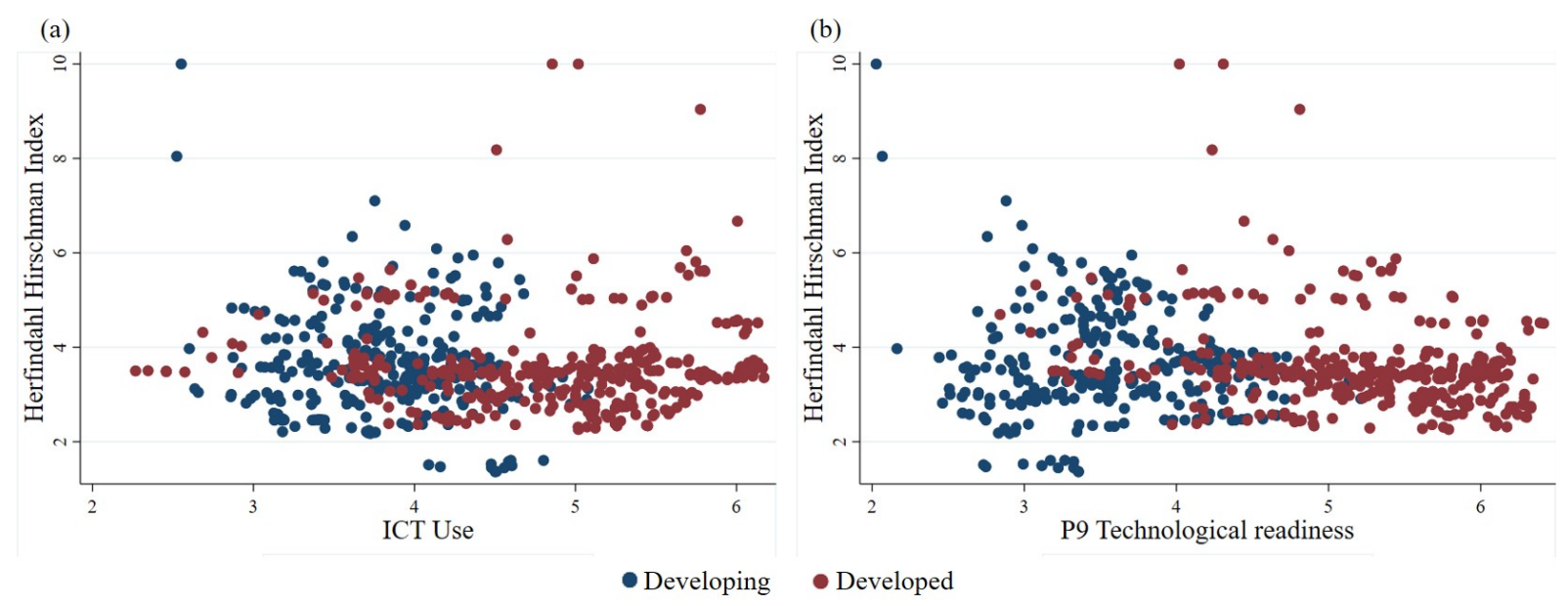

Figure 2: HHI vs Digitisation

Source: Author's calculations. 
Finally, Figure 3 shows the relationship between digitisation and competitiveness. For the sake of simplicity only the ICT use variable is plotted. Panels (a), (c) and (d) reveal a positive correlation between digitisation and the pillars of financial market development, business sophistication and innovation. The correlation is high for both developed and developing countries. Panel (b) shows a positive relationship between ICT use and market size of the economy for developing countries, while for developed countries it is unclear.

(a)

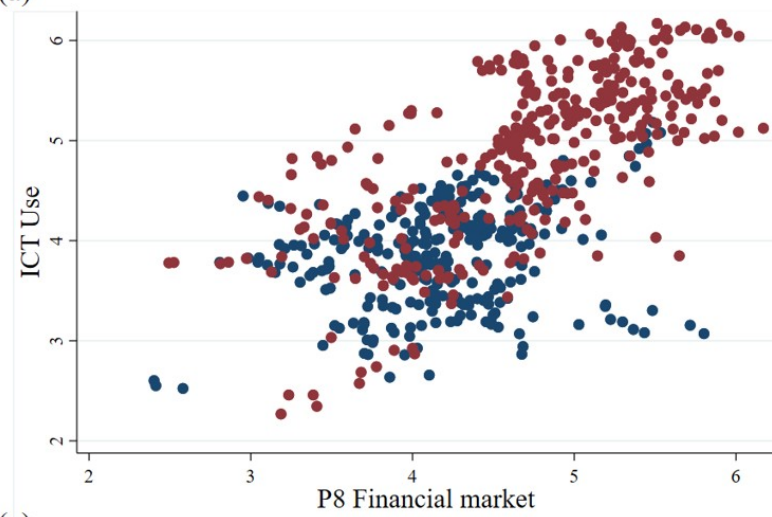

(c)

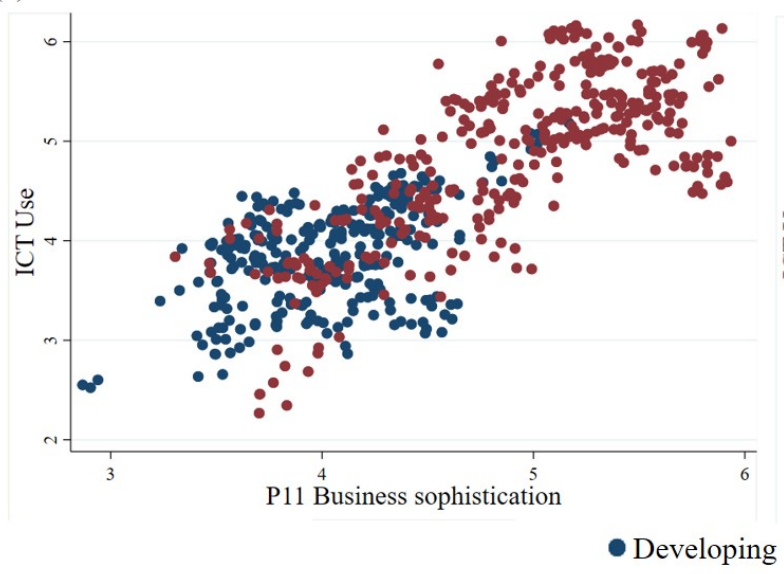

(b)

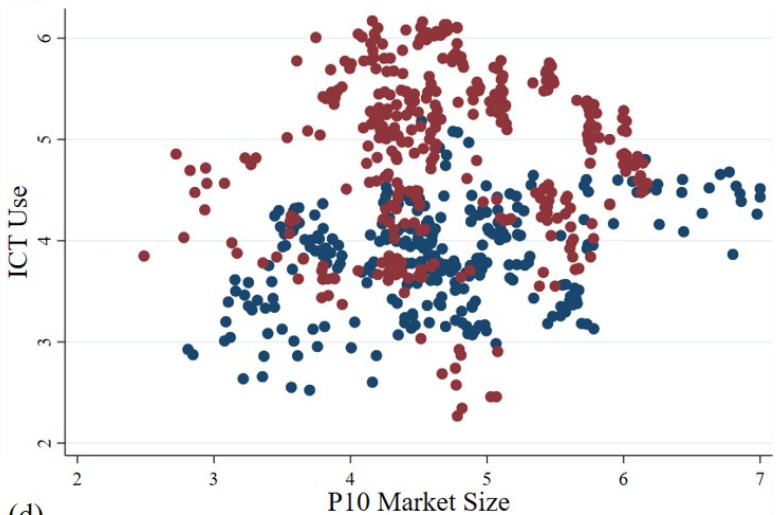

(d)

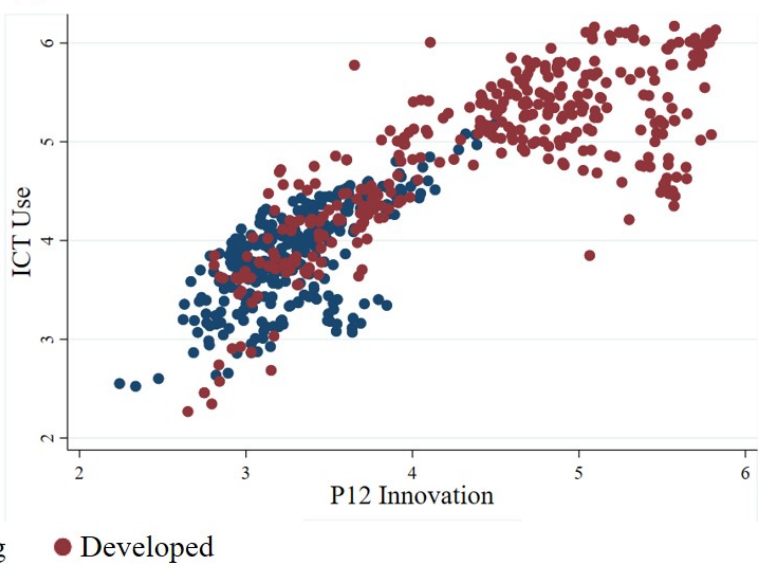

Figure 3: Digitisation vs Competitiveness

Source: Author's calculations.

\section{Empirical Strategy}

Using the panel data of 59 countries from databases described above we want to measure the correlation between concentration of the mobile phone market and competitiveness for countries in the sample. First, we perform the following equation: 


$$
\begin{aligned}
Y_{i t}= & \beta_{0}+\alpha_{t}+\beta_{1} H H I_{i t}+\beta_{2} \text { Inst }_{i t}+\beta_{3} \text { Infra }_{i t}+\beta_{4} \text { AmbMa }_{i t}+\beta_{5} \text { SaludPri }_{i t}+ \\
& \beta_{6} E d u_{i t}+\beta_{6} \text { Efilabor }_{i t}+\varepsilon_{i m}
\end{aligned}
$$

where:

- $Y_{i t}$ measures the competitiveness of country $i$, year $t$;

- $H H I_{i t}$ : Hirschman-Herfindhal index of telecommunication sector in country $i$, year $t$;

- Inst ${ }_{i t}$ : Score of Pilar 1 of GCI: Institutions, country $i$, year $t$;

- Infra $a_{i t}$ : Score of Pilar 2 of GCI: Infrastructure, country $i$, year $t$;

- $A m b M a_{i t}$ : Score of Pilar 3 of GCI: Macroeconomic environment, country $i$, year $t$;

- SaludPri $i_{i t}$ : Score of Pilar 4 of GCI: Macroeconomic environment, country $i$, year $t$;

- Edu $u_{i t}$ : Score of Pilar 5 of GCI: Education, country $i$, year $t$;

- Efilabor E $_{i t}$ Score of Pilar 6 of GCI: Labor market efficiency, country $i$, year $t$.

We use four measures of competitiveness contained in the Global Competitive Index: development of the financial sector, size of the market, business sophistication and innovation.

In a second exercise, we estimate the relationship between the level of concentration in mobile phone markets and the degree of competitiveness of countries in two stages. First, we estimate the relationship between HHI and digitisation. Second, we study the correlation between digitisation and competitiveness variables described above.

The equation we estimate in the first stage is:

$$
D_{i t}=\gamma_{0}+\alpha_{t}+\gamma_{1} H H I_{i t}+\gamma_{2} \text { Inst }_{i t}+\gamma_{3} E d u_{i t}+\gamma_{4} T M_{i t}+\varepsilon_{i m}
$$

Here $D_{i t}$ is a measure of ICT use in country $i$, year $t$, and $T M_{i t}$ is the size of the market (exports and imports) of economy $i$ in year $t$. 
The equation associated to our second stage is:

$$
\begin{aligned}
Y_{i t}= & \beta_{0}+\alpha_{t}+\beta_{1} \hat{D}_{i t}+\beta_{2} \text { Inst }_{i t}+\beta_{3} \text { Infra }_{i t}+\beta_{4} \text { AmbMa }_{i t}+\beta_{5} \text { SaludPri }_{i t}+ \\
& \beta_{6} \text { Edu }_{i t}+\beta_{6}{\text { E } \text { filabor }_{i t}+\epsilon_{i m} .}
\end{aligned}
$$

Finally, we implement an instrumental variable strategy to identify the causal relationship between concentration of mobile phone markets and competitiveness. We use the degree of strictness of antitrust policy as an instrumental variable for HHI. Our claim is that the antitrust policy strictness may directly affect the degree of competition in mobile phone markets without affecting directly the countries' degree of digitisation.

\section{Results}

Our results are presented in Figure 4 and reveal that there is a statistically significant and negative relationship between the concentration of the mobile market and competitiveness for the four indicators. The impact of the HHI on financial market development and innovation is highlighted. An increase of 1000 units in the HHI decreases the value of the first variable by 0.05 and the value of the second one by 0.08 , which is significant considering that the scale of these variables is from 1 to 7 . Likewise, institutions and the macro environment explain part of the good performance of the financial market, while institutions and the efficiency of the labor market significantly affect the other variables of competitiveness contemplated in this study (see Table 2). 


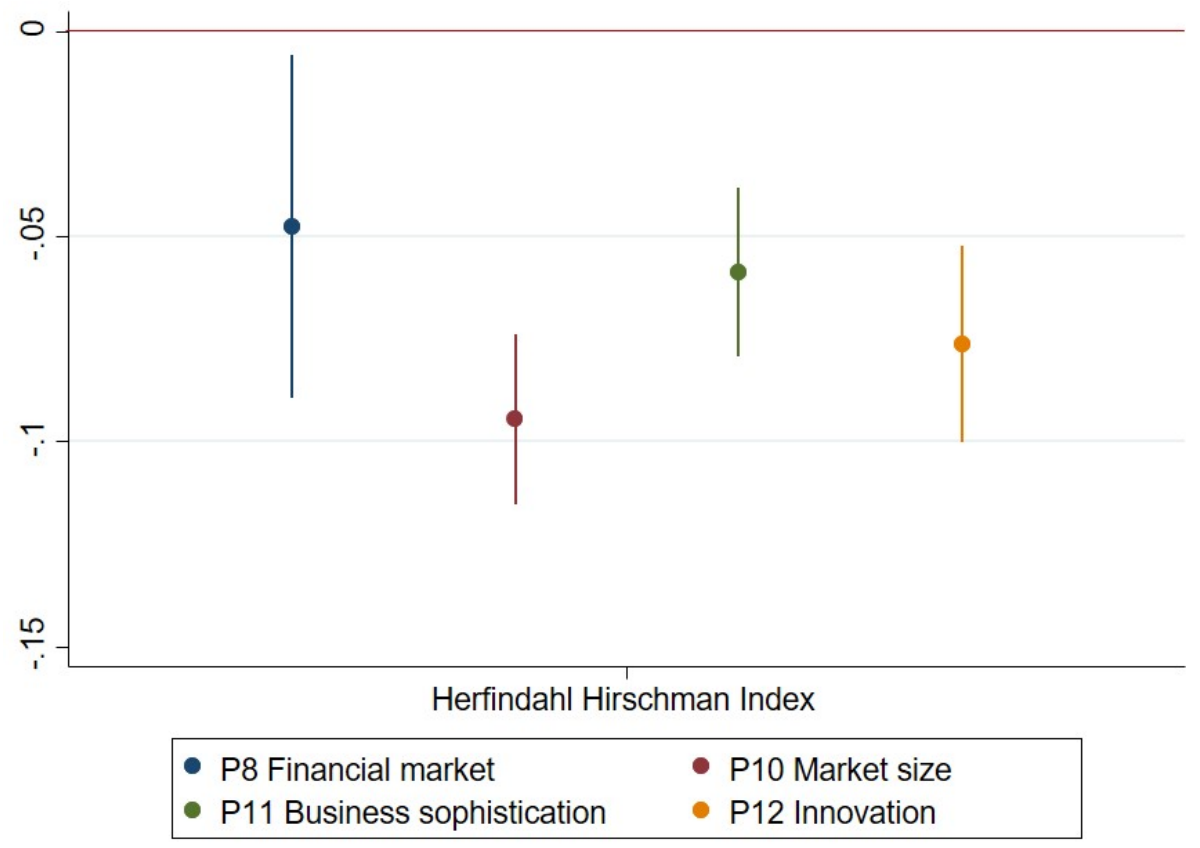

Figure 4: Coefficients associated with HHI vs Competitiveness Variables Note: Confidence intervals with p-value of 0.05 .

In a second exercise, we estimate the impact of ICT on competitiveness using a twostage approach. In the first stage, we aim to explain the relationship between HHI and the variable of ICTs use. In the second stage, we focus on the relationship between the use of ICTs and the competitiveness variables described above. Furthermore, in order to identify if the concentration of the mobile market has a causal relationship on the use of ICT, the first equation of this two-stage procedure is estimated with and without our instrumental variable.

The instrumental variable that is chosen also comes from the decomposition of the GCI. Pillar 6 (Goods Market Efficiency) rates the performance of competition in each country, when evaluating the effectiveness of anti-monopoly policy. This instrumental variable is considered suitable insofar as it explains the HHI without directly explaining the chosen digitisation variables.

The results of the second regression (Figure 5) reveal that there is a negative and significant relationship between competence (HHI) and digitisation, the latter measured by the variables Technological Readiness and ICT use. After the inclusion of effectiveness of antimonopoly policy as instrumental variable, this relationship is maintained and the r-squared increases for the ICT use variable (Table 3). 


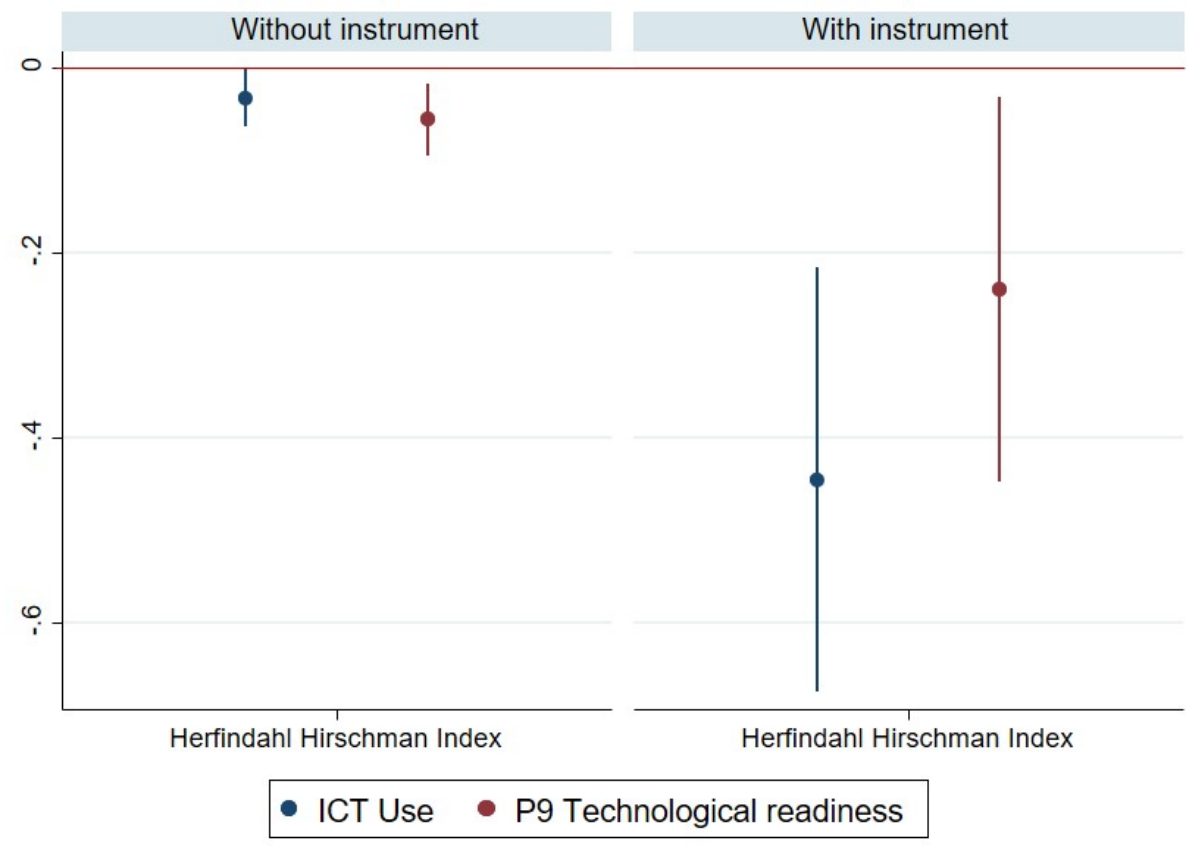

Figure 5: Coefficients associated with HHI vs Digitisation variables Note: Confidence intervals with p-value of 0.05 .

Finally, results shown in Figure 6 reveal that digitisation, measured through the Pillar 9 rating of the GCI, has a positive and significant statistical relationship with business sophistication, while when we measure digitisation through the use of ICT (component of the Pillar 9), the positive and significant relationship occurs with the variables Market size, Business sophistication and Innovation. 


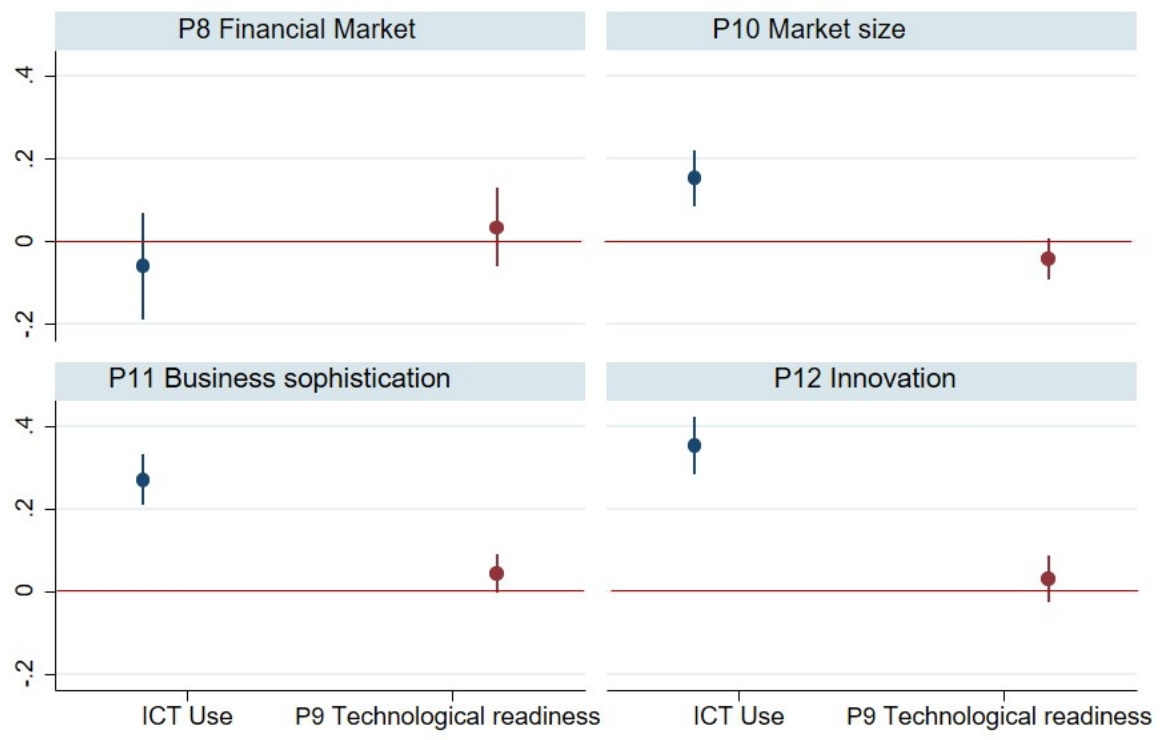

Figure 6: Coefficients associated with Digitisation variables vs Competitiveness variables Note: Confidence intervals with p-value of 0.05 .

\section{Conclusions}

From a database that includes 59 countries, our results reveal that there exists a negative relationship between the concentration in mobile phone markets and countries' competitiveness. Beyond the identification of the causality relationship, our two-stages estimation allows us to shed light on the channel of ICT use that explains why the higher is the concentration the lower is the competitiveness. By this, it is clear that the mobile phone industry is part of an ecosystem that generates spillover effects on the rest of the economy. The most straightforward policy recommendation that one can derive from these results is that all regulations that aim to promote competition in mobile phone markets may generate positive externalities on other sectors of the economy. In this study we focus on the HHI to approximate the degree of competition of mobile phone markets. An interesting extension would be to consider a more direct measure of this competition degree in order to see if for a level of concentration given, there exist other factors that play a role on these positive spillover effects generated by this industry. 


\section{References}

Akerman, A., I. Gaarder and M. Mogstad (2013), "The Skill Complementarity of Broadband Internet", Discussion Paper, No. 7762, IZA Institute for the Study of Labor, Bonn.

Billon, M., Marco, R., and Lera-Lopez, F. Disparities in ICT adoption: A multidimensional approach to study the cross-country digital divide. Telecommunications Policy 33 (2009) 596-610.

Chevalier, C. and A. Luciani (2018), "Computerization, labor productivity and employment: impacts across industries vary with technological level", Documents de travail de la Direction des Études et Synthèses Économiques, No. G2018/02, Institut National de la Statistique et des Études Économiques.

Dhyne, E. Konings, J., Konings, J. and Vanormelingen, S. (2018). "IT and productivity: A firm level analysis," Working Paper Research 346, National Bank of Belgium.

Friesenbichler, K.S. (2007). "Innovation and Market Concentration in Europe's Mobile Phone Industries: Evidence from the Transition from $2 \mathrm{G}$ to $3 \mathrm{G}$ ", WIFO working papers 306/2007.

Frontier Economics (2017). Análisis de Competencia en Mercados Dinámicos. Centro de Estudios de Telecomunicaciones de América Latina (cet.la). December 2017.

Gal, P., Nicoletti, G., Renault, T. Giuseppe Nicoletti, Théodore Renault, Stéphane Sorbe, S., and Timiliotis, C. (2019). OECD Economics Department Working Papers No. 1533. 6 February 2019.

Grimes, A., Ren, C. and Stevens, P. (2012) "The need for speed: impacts of internet connectivity on firm productivity" Journal of Productivity Analysis, Volume 37, Issue 2, pp 187-201. 
Gruber, H. and Koutroumpis, P. "Mobile telecommunications and the impact on economic development" Economic Policy, Volume 26, Issue 67, 1 July 2011, Pages 387-426. OECD (2019), OECD Reviews of Digital Transformation: Going Digital in Colombia, OECD Publishing, Paris, https://doi.org/10.1787/781185b1-en.

Hargittai, E.(1999).Weaving the Western Web: Explaining differences in Internet connectivity among OECD countries. Telecommunications Policy, 23, 701-718.

Kiiski, S., and Pohjola,M.(2002).Cross-country diffusion of the Internet. Information Economics and Policy, 14, 297-310. 


\section{Appendix}

Table 2: Relationship between HHI and Competitiveness

\begin{tabular}{|c|c|c|c|c|}
\hline & $\begin{array}{l}(1) \\
\text { P8 Finan- } \\
\text { cial market }\end{array}$ & $\begin{array}{l}(2) \\
\text { P10 Market } \\
\text { size }\end{array}$ & $\begin{array}{l}(3) \\
\text { P11 Busi- } \\
\text { ness sophis- } \\
\text { tication }\end{array}$ & $\begin{array}{l}(4) \\
\text { P12 Innova- } \\
\text { tion }\end{array}$ \\
\hline $\mathrm{HHI}$ & $\begin{array}{l}-0.05^{* *} \\
(0.02)\end{array}$ & $\begin{array}{l}-0.09^{* * *} \\
(0.01)\end{array}$ & $\begin{array}{l}-0.06^{* * *} \\
(0.01)\end{array}$ & $\begin{array}{l}-0.08^{* * *} \\
(0.01)\end{array}$ \\
\hline P1 Institutions & $\begin{array}{l}0.47^{* * *} \\
(0.06)\end{array}$ & $\begin{array}{l}0.11^{* * *} \\
(0.03)\end{array}$ & $\begin{array}{l}0.28^{* * *} \\
(0.03)\end{array}$ & $\begin{array}{l}0.16^{* * *} \\
(0.04)\end{array}$ \\
\hline P2 Infrastructure & $\begin{array}{l}0.05 \\
(0.03)\end{array}$ & $\begin{array}{l}0.06^{* * *} \\
(0.02)\end{array}$ & $\begin{array}{l}0.00 \\
(0.02)\end{array}$ & $\begin{array}{l}0.02 \\
(0.02)\end{array}$ \\
\hline $\begin{array}{l}\text { P3 Macroeconomic } \\
\text { environment }\end{array}$ & $\begin{array}{l}0.19 * * * \\
(0.02)\end{array}$ & $\begin{array}{l}0.01 \\
(0.01)\end{array}$ & $\begin{array}{l}0.02 \\
(0.01)\end{array}$ & $\begin{array}{l}0.02 \\
(0.01)\end{array}$ \\
\hline \multirow[t]{2}{*}{$\begin{array}{l}\text { P4 Health and pri- } \\
\text { mary education }\end{array}$} & 0.09 & -0.03 & 0.02 & -0.01 \\
\hline & $(0.07)$ & $(0.04)$ & $(0.03)$ & $(0.04)$ \\
\hline \multirow[t]{2}{*}{$\begin{array}{l}\text { P5 Higher education } \\
\text { and training }\end{array}$} & -0.03 & -0.05 & $0.15^{* * *}$ & $0.32^{* * *}$ \\
\hline & $(0.07)$ & $(0.03)$ & $(0.03)$ & $(0.04)$ \\
\hline \multirow[t]{2}{*}{$\begin{array}{l}\text { P7 Labor market ef- } \\
\text { ficiency }\end{array}$} & -0.07 & $-0.09^{* * *}$ & $0.22^{* * *}$ & $0.25 * * *$ \\
\hline & $(0.06)$ & $(0.03)$ & $(0.03)$ & $(0.03)$ \\
\hline Constant & $\begin{array}{l}1.59^{* * *} \\
(0.46)\end{array}$ & $\begin{array}{l}4.81^{* * *} \\
(0.23)\end{array}$ & $\begin{array}{l}1.72^{* * *} \\
(0.23)\end{array}$ & $\begin{array}{l}0.70 * * * \\
(0.26)\end{array}$ \\
\hline Observations & 640 & 640 & 640 & 640 \\
\hline R-squared & 0.474 & 0.537 & 0.497 & 0.545 \\
\hline Number of countries & 59 & 59 & 59 & 59 \\
\hline
\end{tabular}


Table 3: Impact of concentration in the mobile market on digitisation

\begin{tabular}{lll}
\hline & $\begin{array}{l}(1) \\
\text { ICT_use }\end{array}$ & $\begin{array}{l}(2) \\
\text { P9 Technological } \\
\text { readiness }\end{array}$ \\
\hline HHI & $-0.45^{* * *}$ & $-0.24^{* *}$ \\
& $(0.12)$ & $(0.11)$ \\
P5 Higher education & $0.58^{* * *}$ & $0.38^{* * *}$ \\
and training & & \\
& $(0.07)$ & $(0.06)$ \\
P1 Institutions & $0.29^{* * *}$ & 0.07 \\
& $(0.06)$ & $(0.05)$ \\
P10 Market size & $-0.37^{* *}$ & $-0.42^{* * *}$ \\
& $(0.17)$ & $(0.16)$ \\
Constant & $3.92^{* * *}$ & $4.79^{* * *}$ \\
& $(1.29)$ & $(1.17)$ \\
\hline Observations & 640 & 640 \\
Number of countries & 59 & 59 \\
\hline Standard errors in parentheses. ${ }^{* * *} \mathrm{p}<0.01$, & $* * \mathrm{p}<0.05,{ }^{*} \mathrm{p}<0.1$
\end{tabular}

Table 4: Relationship between HHI and Digitisation

\begin{tabular}{lll}
\hline & $(2)$ & $(3)$ \\
& ICT_use & $\begin{array}{l}\text { P9 Technological } \\
\text { readiness }\end{array}$ \\
\hline HHI & $-0.03^{* *}$ & $-0.06^{* * *}$ \\
& $(0.02)$ & $(0.02)$ \\
P5 Higher education & $0.60^{* * *}$ & $0.38^{* * *}$ \\
and training & & \\
& $(0.04)$ & $(0.06)$ \\
P1 Institutions & $0.31^{* * *}$ & 0.08 \\
& $(0.04)$ & $(0.05)$ \\
P10 Market size & $0.17^{* * *}$ & $-0.18^{* *}$ \\
& $(0.06)$ & $(0.07)$ \\
Constant & -0.37 & $2.89^{* * *}$ \\
& $(0.34)$ & $(0.43)$ \\
Observations & 640 & 640 \\
R-squared & 0.479 & 0.731 \\
Number of countries & 59 & 59 \\
\hline Standard errors in parentheses. $* * * \mathrm{p}<0.01, * * \mathrm{p}<0.05, * \mathrm{p}<0.1$
\end{tabular}


Table 5: Relationship between Technological Readiness and Competitiveness

(1) (2) (3) $\quad$ (4)

P8 Finan- P10 Market P11 Busi- P12 Innovacial market size ness sophis- tion tication

\begin{tabular}{|c|c|c|c|c|}
\hline \multirow{2}{*}{$\begin{array}{l}\text { P9 Technological } \\
\text { readiness }\end{array}$} & 0.03 & -0.04 & $0.04^{*}$ & 0.03 \\
\hline & $(0.05)$ & $(0.03)$ & $(0.02)$ & $(0.03)$ \\
\hline P1 Institutions & $\begin{array}{l}0.48^{* * *} \\
(0.06)\end{array}$ & $\begin{array}{l}0.13^{* * *} \\
(0.03)\end{array}$ & $\begin{array}{l}0.29^{* * * *} \\
(0.03)\end{array}$ & $\begin{array}{l}0.17^{* * *} \\
(0.04)\end{array}$ \\
\hline P2 Infrastructure & $\begin{array}{l}0.05^{*} \\
(0.03)\end{array}$ & $\begin{array}{l}0.07^{* * * *} \\
(0.02)\end{array}$ & $\begin{array}{l}0.01 \\
(0.02)\end{array}$ & $\begin{array}{l}0.03 \\
(0.02)\end{array}$ \\
\hline $\begin{array}{l}\text { P3 Macroeconomic } \\
\text { environment }\end{array}$ & $0.20^{* * *}$ & $(0.01)$ & $(0.01)$ & $(0.01)$ \\
\hline $\begin{array}{l}\text { P4 Health and pri- } \\
\text { mary education }\end{array}$ & $\begin{array}{l}0.07 \\
(0.07)\end{array}$ & $\begin{array}{l}-0.06 \\
(0.04)\end{array}$ & $\begin{array}{l}-0.00 \\
(0.04)\end{array}$ & $\begin{array}{l}-0.03 \\
(0.04)\end{array}$ \\
\hline $\begin{array}{l}\text { P5 Higher education } \\
\text { and training }\end{array}$ & $\begin{array}{l}-0.04 \\
(0.07)\end{array}$ & $\begin{array}{l}-0.03 \\
(0.04)\end{array}$ & $\begin{array}{c}0.13^{* * *} \\
(0.04)\end{array}$ & $\begin{array}{c}0.31^{* * *} \\
(0.04)\end{array}$ \\
\hline $\begin{array}{l}\text { P7 Labor market ef- } \\
\text { ficiency }\end{array}$ & -0.06 & $\begin{array}{l}-0.08^{* *} \\
(0.03)\end{array}$ & $0.22^{* * *}$ & $\begin{array}{l}0.26^{* * *} \\
(0.04)\end{array}$ \\
\hline Constant & $\begin{array}{l}1.32^{* * *} \\
(0.47)\end{array}$ & $\begin{array}{l}4.51^{* * * *} \\
(0.25)\end{array}$ & $\begin{array}{l}1.39^{* * *} \\
(0.23)\end{array}$ & $\begin{array}{l}0.32 \\
(0.27)\end{array}$ \\
\hline Observations & 640 & 640 & 640 & 640 \\
\hline R-squared & 0.469 & 0.473 & 0.472 & 0.515 \\
\hline Number of countries & 59 & 59 & 59 & 59 \\
\hline
\end{tabular}


Table 6: Relationship between ICT use and Competitiveness

\begin{tabular}{|c|c|c|c|c|}
\hline & $\begin{array}{l}(1) \\
\text { P8 Finan- } \\
\text { cial market }\end{array}$ & $\begin{array}{l}(2) \\
\text { P10 Market } \\
\text { size }\end{array}$ & $\begin{array}{l}(3) \\
\text { P11 Busi- } \\
\text { ness sophis- } \\
\text { tication }\end{array}$ & $\begin{array}{l}(4) \\
\text { P12 Innova- } \\
\text { tion }\end{array}$ \\
\hline ICT_use & $\begin{array}{l}-0.06 \\
(0.07)\end{array}$ & $\begin{array}{l}0.15^{* * *} \\
(0.03)\end{array}$ & $\begin{array}{l}0.27^{* * *} \\
(0.03)\end{array}$ & $\begin{array}{l}0.35 * * * \\
(0.04)\end{array}$ \\
\hline P1 Institutions & $\begin{array}{l}0.49 * * * \\
(0.06)\end{array}$ & $\begin{array}{l}0.10^{* * *} \\
(0.03)\end{array}$ & $\begin{array}{l}0.24^{* * *} \\
(0.03)\end{array}$ & $\begin{array}{l}0.11^{* * *} \\
(0.03)\end{array}$ \\
\hline P2 Infrastructure & $\begin{array}{l}0.06^{*} \\
(0.03)\end{array}$ & $\begin{array}{l}0.05^{* * *} \\
(0.02)\end{array}$ & $\begin{array}{l}-0.02 \\
(0.02)\end{array}$ & $\begin{array}{l}-0.01 \\
(0.02)\end{array}$ \\
\hline $\begin{array}{l}\text { P3 Macroeconomic } \\
\text { environment }\end{array}$ & $\begin{array}{l}0.19 * * * \\
(0.02)\end{array}$ & $\begin{array}{l}0.01 \\
(0.01)\end{array}$ & $\begin{array}{l}0.02^{* *} \\
(0.01)\end{array}$ & $\begin{array}{l}0.03^{* *} \\
(0.01)\end{array}$ \\
\hline $\begin{array}{l}\text { P4 Health and pri- } \\
\text { mary education }\end{array}$ & $\begin{array}{l}0.08 \\
(0.07)\end{array}$ & $\begin{array}{l}-0.09^{* *} \\
(0.04)\end{array}$ & $\begin{array}{l}-0.05 \\
(0.03)\end{array}$ & $\begin{array}{l}-0.10^{* *} \\
(0.04)\end{array}$ \\
\hline $\begin{array}{l}\text { P5 Higher education } \\
\text { and training }\end{array}$ & $\begin{array}{l}0.00 \\
(0.08)\end{array}$ & $\begin{array}{l}-0.13^{* * *} \\
(0.04)\end{array}$ & $\begin{array}{l}0.00 \\
(0.04)\end{array}$ & $\begin{array}{l}0.13^{* * *} \\
(0.04)\end{array}$ \\
\hline $\begin{array}{l}\text { P7 Labor market ef- } \\
\text { ficiency }\end{array}$ & -0.05 & $-0.12^{* * *}$ & $0.16 * * *$ & $0.18^{* * *}$ \\
\hline Constant & $\begin{array}{l}(0.06) \\
1.30 * * * \\
(0.46)\end{array}$ & $\begin{array}{l}(0.03) \\
4.65^{* * *} \\
(0.24)\end{array}$ & $\begin{array}{l}(0.03) \\
1.89^{* * *} \\
(0.22)\end{array}$ & $\begin{array}{l}(0.03) \\
0.92^{* * *} \\
(0.25)\end{array}$ \\
\hline $\begin{array}{l}\text { Observations } \\
\text { R-squared } \\
\text { Number of countries }\end{array}$ & $\begin{array}{l}640 \\
0.470 \\
59\end{array}$ & $\begin{array}{l}640 \\
0.489 \\
59\end{array}$ & $\begin{array}{l}640 \\
0.532 \\
59\end{array}$ & $\begin{array}{l}640 \\
0.585 \\
59\end{array}$ \\
\hline
\end{tabular}

